\title{
War and Faith: Memories of the Great Patriotic War in the Russian Orthodox Church
}

Christian Basar

Despite previous anti-religious persecution, the Russian Orthodox Church became a valuable support for the Soviet state during the Great Patriotic War against Hitler's Germany. Though the Soviet Union and its atheistic system of government no longer exists, the modern Church memorializes the War as a fight for "Holy Russia." This memory of the war may seemingly contradict the legacy of Soviet oppression against Christians, but the idea of "Holy Russia" makes these memories compatible. The Orthodox remembrance of the war also involves politics, considering the faith's importance in Russia and the use of the Great Patriotic War as a politically legitimizing idea.

When a country is under the threat of foreign invasion, any possible weapon can or will be used in the fight. The same was true during the Soviet Union's Great Patriotic War with Nazi Germany, when the Russian Orthodox Church (ROC) helped rouse the Soviet people to the war effort, despite the fact that it had been persecuted under an atheistic Communist government. In modern times, the Church has revered the Soviet Union's epic, "holy" battle for survival. But the religious memory of the war is somewhat complicated. How does the memory of anti-religious Communist persecution fit with that of "Holy Russia" fighting Nazism? In this paper we will gain some insight into this contradiction. We will also survey some manifestations of the ROC's perspective of the Great Patriotic War, including its memory rituals, literature, and even national exceptionalism in some cases.

According to an article published on the website Pravda.ru, the Nazi invasion of the Soviet Union on June 22, 1941 helped save the ROC which had been living under a regime hostile to 
religion. ${ }^{1}$ The crisis was presented as an event that turned the atheistic nation back to God. In 1943, Stalin made an about-face regarding religion, no longer interested in actively persecuting the church. The article says this is evident because at the start of the war, between 150 and 400 parishes were active in the Soviet Union. But after a few years, this number increased to 22,000. A monk was quoted in this article, who supposedly prophesied in 1918 that Germany would invade Russia, actually making Russia stronger. The article notes that the Great Patriotic War with the German invaders continued until May 1945, corresponding to the holidays of George the Victorious and Easter. The war was thus given a religious element. Even more powerful was how the article connected the nation's wartime sacrifices and suffering with the revival of religiosity and the salvation of peoples souls.

It is well known that the Soviet government persecuted Orthodox Christianity, as mentioned in the Pravda.ru article. Yet this same article paints a positive picture of the Soviet war effort. What is behind this apparent contradiction? To answer this question, we must first look at Russia's relationship with its dominant religion. How does this relationship in turn affect the view of foreigners in general, and specifically the war against the German invaders of 1941? This will help us analyze what the modern ROC thinks of the Great Patriotic War.

For many individuals, one's faith is a critical part of his or her identity. If enough people identify with a religion, it may become part of their national identity and culture. The Russian people are an example of this. For many, the ROC is essential to Russianness. It has been said that during the Tsarist regime, Russia had three defining characteristics: "Autocracy, Orthodoxy, [and] Nationality." Russia was even known as the "Third Rome" - the last stand of "true Christianity." were a kind-of "chosen people" and their nation was the final stand of true Christianity. In Russia, religion was certainly not simply a matter of individual belief. "Holy Russia" is a term often used to describe the Russian relationship with Orthodoxy.

The same is true in the post-Soviet era. A survey conducted in 1996 found that 83 percent of religious Russians were Orthodox. ${ }^{4}$ Being Orthodox is equivalent to being Russian; indeed, the

\footnotetext{
${ }^{1}$ Maria Gousseva, trans., "Hitler's invasion of USSR revived Russian Orthodox Church,” PRAVDA.ru, September 13, 2006, http://english.pravda.ru/history/13-09-2006/84417-hitler-0/.

${ }^{2}$ Juliet Johnson, "Religion after Communism: Belief, Identity, and the Soviet Legacy in Russia," in Religion and Identity in Russia: The Revival of Orthodoxy and Islam, ed. Juliet Johnson et al. (Burlington: Ashgate Publishing Company, 2005), 3.

${ }^{3}$ John Strickland, introduction to The Making of Holy Russia: The Orthodox Church and Russian Nationalism before the Revolution (Jordanville, NY: Holy Trinity Publications, 2013), x. Ibid., 88-9.

Svetlana Ryzhova, "Tolerance and Extremism: Russian Ethnicity in the Orthodox Discourse of the 1990s," in Religion and Identity in Russia, 73-4.

${ }^{4}$ Johnson, "Religion after Communism," in Religion and Identity in Russia, 15.
} 
Orthodox identity is part of Russian ethnicity and the national "soul." This has led to radical national-religious views which do not have the blessing of the Patriarchate - the leadership of the "official" Russian Orthodox Church. ${ }^{6}$ Such views include the doctrine that God "asks" Russians to be Russian. The idea here is that Russians have divine favour, and groups such as the Resurrection Orthodox Brotherhood hold to perceptions of ethnic exceptionalism.

In several ways, this ethnic aspect of Russian Orthodoxy has overridden actual religious practice and belief. Studies discovered that some Russians identified primarily with their ethnicity, not their religious practice. " There were many "Orthodox" that did not even believe in God. Such atheists maybe became "religious" in order to fit in with their religious society. Or perhaps they adopted a faith identity that reinforced their ethnicity. Father Georgii Chistiakov wrote that in the 1990s, some "Orthodox" simply used their faith as a lens through which they viewed non-Russians as the "Other." This "Othering" led to an intense fear of foreigners, Catholics, and Protestants, as well as a suspicion of "Christian unity" movements. In such cases, this power of religious identity has been combined with the national defensive ideology of the Tsarist period. ${ }^{8}$ This wing of Orthodoxy has become an ideology like that of old nationalism. ${ }^{9}$

But things were very different for the Orthodox Christians in the Soviet period. Marxist-Leninist ideology, upon which the Soviet Union was built, was vehemently anti-religious. ${ }^{10}$ Faith was believed to be a distraction from the vision of proletarian revolution, as well as a "divisive manifestation of false consciousness." Both Christians and Muslims suffered martyrdom by the thousands under Soviet religious persecution. ${ }^{11}$ ROC monasteries were closed and many church buildings were destroyed or "repurposed" to serve the needs of the Communist Party. Coercive pressure was placed on priests and on parents who had their children baptized. ${ }^{12}$ Religion was an "anti-Soviet" activity that the government mercilessly attempted to extinguish.

How did this affect the Soviet Union during World War II? One might think that Orthodox Christians would rejoice at the German invasion. One might imagine Christians across the USSR singing "Hallelujah! Our godless Soviet oppressors will finally be destroyed!" Yet this

\footnotetext{
${ }^{5}$ Ibid., 20.

Father Georgii Chistiakov, "In Search of the 'Russian Idea': A View from Inside the Russian Orthodox Church," in Religion and Identity in Russia, 60.

${ }^{6}$ Ibid., 57-61.

7 Johnson, "Religion after Communism," in Religion and Identity in Russia, 20.

Marietta Stepaniants, "Ethno-Religious Identity in Modern Russia: Orthodoxy and Islam Compared," in Religion and Identity in Russia, 26-7.

${ }^{8}$ Chistiakov, quoted in Marietta Stepaniants, "Ethno-Religious Identity in Modern Russia: Orthodoxy and Islam

Compared," in Religion and Identity in Russia, 27.

${ }^{9}$ Chistiakov, "In Search of the 'Russian Idea'," in Religion and Identity in Russia, 61.

${ }^{10}$ Johnson, "Religion after Communism," in Religion and Identity in Russia, 3.

${ }^{11}$ Ibid., 5-6.

${ }^{12}$ Chistiakov, "In Search of the 'Russian Idea'," in Religion and Identity in Russia, 53.
} 
was not the reality. The Patriarchal locum tenens, Metropolitan Sergey Stragorodsky, wrote a rousing letter on June 22, 1941 - the very day of the German attack. ${ }^{13}$ In his "Message to the Pastors and Flock of Christ's Orthodox Church," he wrote about the "antichrist essence of fascism" and called for the defense of the Soviet Union against the "wretched offspring of the enemies of Orthodox Christianity."

Why would Orthodox Christians fight for the state that had brutally oppressed them before the war? It must be remembered that Russia was culturally and historically Orthodox, despite the present Soviet reality. ${ }^{14}$ Kievan Rus', considered Russia's ancient predecessor, converted to Eastern Christianity in 988. ${ }^{15}$ The Soviet Union was only a few decades old by the start of the Great Patriotic War. According to some, this fact forced Stalin to tone down the Soviet anti-religious rhetoric. $^{16}$ In 1943, restrictions on religion were eased and the Moscow Patriarchate was recreated. This also served to reunite Orthodox Christianity. It allowed the Muscovite religious organization to resume its dominant role in the faith, at the expense of the Renovationist Church, which was a pro-Soviet faction whose origins went all the way back to the Revolution of 1905 . $^{17}$

The war with Germany was thus a period of restoration for the ROC. In October 1941, well before the 1943 resurrection of the Patriarchate, Metropolitan Sergey held a meeting with clergymen, he conducted ordinations, and they discussed the restoration of religious life. ${ }^{18}$ It is quite ironic that Stalin might become the Church's earthly savior in 1943, officially ending the persecution. But under the new paradigm of church-state cooperation, there were significant efforts to strengthen the ROC. For example, Stalin gave the Church its own bank accounts, which it used to make donations to the war effort. ${ }^{19}$

\footnotetext{
${ }^{13}$ Dimitry Pospielovsky, vol. 1 of The Russian Church under the Soviet Regime (Crestwood, NY: St. Vladimir's Seminary Press, 1984), 193-6.

M.I. Odintsov, "K istorii Russkoi Tserkvi v godoi Velikoi Otchestvyennoi voiniy (kommentapi v tsfrakh i faktakh," Sinodalnoi Otdel Moskovskovskovo Patriarkhata po vzaimodaystviyu s Vooruzhennimi Silami i pravookhranitelnimi organami, February 21, 2015, trans. Christian Basar, http://pobeda.ru/k-istorii-russkoy-tserkvi-v-godyi-velikoy-otechestvennoy-voynyi-kommentariy-v-tsifrah-i-faktah.ht $\mathrm{ml}$.

${ }^{14}$ Katja Richters, The Post-Soviet Russian Orthodox Church: Politics, Culture and Greater Russia (New York: Routledge, 2013), 66.

15 Thomas Bremer, Cross and Kremlin: A Brief History of the Orthodox Church in Russia (Cambridge: Wm. B. Eerdmans Publishing Co., 2013), 8-9.

${ }^{16}$ Richters, The Post-Soviet Russian Orthodox Church, 66.

${ }^{17}$ Edward E. Roslof, Red Priests: Renovationism, Russian Orthodoxy, and Revolution, 1905-1946 (Bloomington, IN: Indiana University Press, 2002), 36-7, 190-3.

Pospielovsky, The Russian Church Under the Soviet Regime, 1917-1982, 53-5.

${ }^{18}$ Odintsov, "K istorii Russkoi Tserkvi v godoi Velikoi Otchestvyennoi voini."

${ }^{19}$ Ibid., 67.
} 
As a persecutor of the Church, Stalin would certainly have been viewed as an enemy of God. Yet others have held the opposite view, including a modern Orthodox priest, Dmitrii Dudko. ${ }^{20}$ Dudko wanted Stalin's image to be rehabilitated, for in his view, Stalin "appeared" to be an atheist, but he was actually a Christian. The restoration of the Moscow Patriarchate would fit with this narrative. Another religious account, written in 2006, mentions how Stalin helped the ROC but fails to discuss his battle against faith before the German invasion. ${ }^{21}$ Katja Richters notes that in 2006, during the Patriarchate of Alexei II, Stalin's atheism was ignored. In such literature, Stalin helped the Church and was an effective military commander.

The work of Kathy Rousselet should be mentioned here, for it explains how the painful legacy of atheistic Communism is molded with the ROC's memory of the War against Hitler as a holy struggle. $^{22}$ After the glasnost (openness) period of the 1980 's, society was able to delve into Stalin's oppression against religion, and now the Church could conduct research on and publish books about this topic. "Churches on Spilled Blood" became sites that memorialized the victims of Communist atheism, and these churches allowed religious services to be held for them. The anti-religious Soviet Union thus became in memory a "martyr nation," but it was also "Holy Russia" that fought Nazism in the 1940s. Rousselet suggests that the martyrs became examples for modern Orthodox Christians; she argues that this religious memorialization of the Stalinist period makes the martyrs like the heroes of the Great Patriotic War. The martyrs died for the sake of the Orthodox "Holy Russia," and not the Soviet Union. In this way, Rousselet says, they continued the legacy of the Russians that fought the Tatars and Napoleon. They "fought" for the same national ideal as the Soviet Union's soldiers.

Patriotism was certainly a factor in the ROC during the Great Patriotic War. We have read some of Metropolitan Sergey's letter of June 22, 1941. It was hardly a lacklustre response to the invasion. As Dimitrii Pospielovsky said, the church leader wrote this letter on the first day of the war, while Stalin hid from the public for ten days. ${ }^{23}$ At the war's beginning, Sergey the Churchman showed more initiative and resolve than Stalin. A new, modern version of the "Third Rome" could be seen in which the Soviet nation was sacred, and religion was only too glad to help stoke the fires of patriotism. ${ }^{24}$ Patriotism can appeal to almost anyone, whether or not they are religious. This national fervour was evident within the body of believers. For in response to Metropolitan Sergey's address, church members are said to have voluntarily donated

\footnotetext{
${ }^{20}$ Chistiakov, "In Search of the 'Russian Idea'," in Religion and Identity in Russia, 60.

${ }^{21}$ Richters, The Post-Soviet Russian Orthodox Church, 67.

${ }^{22}$ Kathy Rousselet, "The Russian Orthodox Church and Reconciliation with the Soviet Past History, Memory and Politics in Central and Eastern Europe: Memory Games, ed. Georges Mink and Laure Neumayer (New York: Palgrave Macmillan, 2013): 39-43, 46-8, 50.

${ }^{23}$ Pospielovsky, The Russian Church under the Soviet Regime, 194.

${ }^{24}$ Paul B. Anderson, People, Church and State in Modern Russia (New York: The MacMillan Company, 1944), 194.
} 
money, government loans, jewelry, and footwear to the needs of the frontlines. ${ }^{25}$ Orthodox Christians also collected funds for the raising of a "Dmitrii Donskoi" armored division.

Russian Orthodoxy looks back with pride upon the eventual Soviet defeat of Nazi Germany. ${ }^{27}$ In both Russia and Belarus, the Church commemorates the victory over fascism, and in their official commemorations they are grateful for the Soviet Union's defenders during that conflict. On August 16, 2013, the $70^{\text {th }}$ anniversary of the Battle of Kursk, the Patriarch of Moscow and All Russia Kirill met with veterans of the Great Patriotic War. ${ }^{28}$ These veterans had fought in battles from the Siege of Moscow to the Battle of Berlin, and the Patriarch awarded some of them with the Orthodox Church's religious decorations. This ceremony occurred in the rebuilt cathedral known as "Church of Christ the Savior," a church that was first built after the Russian Empire beat the French Emperor Napoleon in $1812 .{ }^{29}$

On May 9, 2014, Orthodox youths celebrated Victory Day in Moscow by praying for deceased soldiers and then setting out for Gorky Park. ${ }^{30}$ Some wore World War II-era military garb as they congratulated veterans with gifts and flowers. Veterans thanked the youngsters and spoke earnestly about their wartime experiences. They talked about being atheists before the war but eventually coming to Orthodoxy. God was with them, they believed, in hopeless situations, which allowed them and the nation to emerge victorious. The veterans still cherished this triumph. But they also spoke about compassion, the seeds of which were said to have been planted during the war's dark days.

The conflict has been perceived as a moment through which Russia's soul was tested and purged. Numerous religious stories appear in which the war has a great effect on individuals. We already looked at veterans learning to trust God through their time on the front. There is also the story of a "Letter to God." Supposedly, this letter was found on a soldier killed in the war, but its actual authenticity is doubted. The soldier wrote about looking at a beautiful night sky and coming to belief in God. He berates himself for not having faith earlier in his life, and he asks God to

\footnotetext{
${ }^{25}$ Odintsov, "K istorii Russkoi Tserkvi v godoi Velikoi Otchestvyennoi voini."

${ }^{26}$ Richters, The Post-Soviet Russian Orthodox Church, 67.

${ }^{27}$ Richters, The Post-Soviet Russian Orthodox Church, 131-2.

28 "Svyatei Patriarch Moskovskiy i vsyeya Rysi Kihrill vstrtilsya s veteranami Velikoi Otechestvennoi voiniy," Moskovskaya Eparkhiya, trans. Christian Basar, August 20, 2013, http://www.moseparh.ru/news/text/15431.html.

${ }^{29}$ Richters, The Post-Soviet Russian Orthodox Church, 66.

John Garrard and Carol Garrard, Russian Orthodoxy Resurgent: Faith and Power in the New Russia (Princeton: Princeton University Press, 2008), 82-3.

30 "Chleniy pravoslavnovo molodezhnovo obshestva 'Pokrov' pozdravili uchastnikov Velikoi Otechestvennoi voiniy s Dnyem Pobedi,” Moskovskaya Eparkhiya, trans. Christian Basar, May 12, 2014, http://www.moseparh.ru/news/text/26540.html.

${ }^{31}$ Richters, The Post-Soviet Russian Orthodox Church, 68-9.
} 
forgive his past atheism. In such narratives, the war strikes fear in soldiers' hearts, which draws them to faith.

In this kind of literature, God cared for soldiers, but the war also had a cathartic effect on peoples' souls. Metropolitan Sergey himself said as much in 1941, believing the war would heal national spirituality and cure such ills as selfishness and the lack of patriotism. ${ }^{32}$ The war was a battle of civilizations, according to one A. Kravchenko. ${ }^{33} \mathrm{He}$ argued that at the Battle of Stalingrad, the "rational," irreligious civilization of Nazi Germany tried to defeat the Soviet Union's conservative, idealistic, and religious culture. When the Russians (Orthodoxy) ultimately won at Stalingrad, it was a victory for spirituality.

The Department for Relations with the Armed Forces and Law Enforcement Agencies (DRAFLEA) is an important propagator of this religious narrative about the Great Patriotic War. ${ }^{34}$ The ROC created this organization in July 1995 as part of the Church's role in Russian society. DRAFLEA's purpose, as defined in 1996, is to serve soldiers' spiritual needs, establish places of worship for the military, and educate soldiers to become better Christians and patriots. This group has produced much of the material described above, such as the "Letter to God" and A. Kravchenko's views on Stalingrad. $^{35}$ There was also DRAFLEA's director, Father Dimitrii Smirnov. $^{36}$ In 2003, he spoke of soldiers' sacrifices during the Great Patriotic War in the light of Jesus Christ's words: "No one has greater love than this, to lay down one's life for one's friends." ${ }^{37}$ Smirnov took the word "friends" to mean "fellow citizens," equating patriotic sacrifice with Christ's command for Christians to love and perhaps even die for each other. In 1941, Metropolitan Sergey himself quoted this passage of scripture in reference to any soldier or other patriot who would suffer the ultimate sacrifice for the country's safety. ${ }^{38}$

I believe it is worthwhile to briefly discuss the memory of the war and political legitimacy. In 2014, a rather critical article was posted on the website New Republic. It suggested that a common historical memory is Russia's only suitable unifier, since Russia is a large country with multiple languages. ${ }^{39}$ The only other thing that Russia's citizens have in common, believed the

\footnotetext{
${ }^{32}$ Anderson, People, Church and State in Modern Russia, 196-7.

${ }^{33}$ Richters, The Post-Soviet Russian Orthodox Church, 66.

${ }^{34}$ Ibid., 57-9.

${ }^{35}$ Ibid., 66, 68-9.

${ }^{36}$ Richters, The Post-Soviet Russian Orthodox Church, 66.

37 John 15:13 (New Revised Standard Version).

${ }^{38}$ Acting Patriarch Sergius, "Foreword: The Purpose of this Book," in The Truth about Religion in Russia, edited by Nicholas Yarushevich, Gregory Petrovich Georgievsky, and Alexander Pavlovich Smirnov. London: Hutchinson \& Co. (Publishers), Ltd., 1942), 9.

${ }^{39}$ Tikhon Dzyadko, "Putin Is Using WWII for Propaganda Because It's the Best Memory that Russia Has," New Republic, April 22, 2014, http://www.newrepublic.com/article/117479/russia-world-war-ii-vIctory-putins -obsession.
} 
author, is a corrupt governmental system. This article was in fact very critical of Russian culture, arguing that the county has no effective national memory other than the Great Patriotic War. According to this view, the war is the country's only historical event that is unambiguous. It affected so many people that most modern Russians agree on it, regardless of their background or language.

President Vladimir Putin has appropriated this memory to increase his legitimacy. By summoning the memory of Russia's defeat of fascism back in 1945, he suggests that Russia still has a role to play in maintaining world peace and security. According to the article we just studied, Putin even uses the Great Patriotic War's religious element by associating himself with the unification of Orthodoxy. Considering the importance of Orthodoxy in Russian society, the positive impact of this on Putin's legitimacy is obvious.

The memory of World War II in Russia has caused strained relationships with foreign nations, and the ROC has been involved in these controversies. The Soviet victory in the Great Patriotic War allowed Russian rule and influence to expand. ${ }^{40}$ In the post-Soviet world, this has caused the Russian government and the ROC to get involved in their neighbors' internal affairs when it appeared that Russia's national memory was being insulted. For example, in Estonia, a statue called the Bronze Soldier had been built in memory of Soviet soldiers who lost their lives in World War II. ${ }^{41}$ But in May 2007, the Estonian government moved the monument to an Estonian military cemetery. Vladimir Putin's government condemned the action. But Alexey II, then Patriarch of the ROC, also got political by agreeing with the Russian state, calling the Estonian government's move a sacrilegious disregard of wartime sacrifice. This sacrifice, he argued, was part of the Soviet heritage which both Russians and Estonians shared. He believed this indicated that fascism was again rearing its ugly head. The Patriarch also suggested that the Estonian government wanted to insult Russians. In saying this, Alexey repeated the xenophobic views of some nationalistic Orthodox Russians.

It is important to realize that in Russia, the Church and State do not always see eye to eye. ${ }^{42}$ For instance, though Alexey II supported the Russian government in the case of the Bronze Soldier, he did not want his Church to become an agent of the state. But Katja Richters reminds us that the government and the Russian Church might take similar actions because they both want to preserve the memory of times when Russia was a great power. This includes the memory of World War II. The religious character of the war is an undeniable part of this memory, as we have seen in the DRAFLEA writings, religious nationalism, the ROC's commemoration of veterans, and the Patriarch's involvement in foreign controversy over monuments. Considering

\footnotetext{
${ }^{40}$ Richters, The Post-Soviet Russian Orthodox Church, 94.

${ }^{41}$ Ibid., 90.

${ }^{42}$ Ibid., 61, 94.
} 
the extreme importance of both the Great Patriotic War and Orthodoxy in Russian society and politics, it is unlikely that the narrative of God's struggle against fascism will go away anytime soon. 


\section{Bibliography}

Acting Patriarch Sergius. "Foreword: The Purpose of this Book." In The Truth about Religion in Russia, edited by Nicholas Yarushevich, Gregory Petrovich Georgievsky, and Alexander Pavlovich Smirnov, 5-9. London: Hutchinson \& Co. (Publishers), Ltd., 1942.

Anderson, Paul B. People, Church and State in Modern Russia. New York: The MacMillan Company, 1944.

Bremer, Thomas. Cross and Kremlin: A Brief History of the Orthodox Church in Russia. Cambridge: Wm. B. Eerdmans Publishing Co., 2013.

Chistiakov, Father Georgii. "In Search of the 'Russian Idea': A View from Inside the Russian Orthodox Church." In Religion and Identity in Russia: The Revival of Orthodoxy and Islam, edited by Juliet Johnson, Marietta Stepaniants, and Benjamin Forest, 53-64. Burlington: Ashgate Publishing Company, 2005.

“Chleniy pravoslavnovo molodezhnovo obshestva 'Pokrov' pozdravili uchastnikov Velikoi Otechestvennoi voiniy s Dnyem Pobedi." Moskovskaya Eparkhiya. Translated by Christian Basar. May 12, 2014. http://www.moseparh.ru/news/text/26540.html.

Dzyadko, Tikhon. "Putin Is Using WWII for Propaganda Because It's the Best Memory that Russia Has.” New Republic. April 22, 2014. http://www.newrepublic.com/article/11747 9/russia-world-war-ii-victory-putins-obsession.

Garrard, John and Carol Garrard. Russian Orthodoxy Resurgent: Faith and Power in the New Russia. Princeton: Princeton University Press, 2008.

Gousseva, Maria, trans. PRAVDA.ru. "Hitler's invasion of USSR revived Russian Orthodox Church.” September 13, 2006. http://english.pravda.ru/history/13-09-2006/84417-hi tler-0/.

Holy Bible - New Revised Standard Version: Catholic Edition, Anglicized Text. New York: HarperCollins Publishers, 2007.

Johnson, Juliet. "Religion after Communism: Belief, Identity, and the Soviet Legacy in Russia." In Religion and Identity in Russia: The Revival of Orthodoxy and Islam, edited by Juliet Johnson, Marietta Stepaniants, and Benjamin Forest, 1-25. Burlington: Ashgate Publishing Company, 2005.

Odintsov, M.I. "K istorii Russkoi Tserkvi v godoi Velikoi Otchestvyennoi voiniy (kommentapi v tsfrakh i faktakh." Sinodalnoi Otdel Moskovskovskovo Patriarkhata po vzaimodaystviyu s Vooruzhennimi Silami i pravookhranitelnimi organami. Translated by Christian Basar. February 21, 2015. http://pobeda.ru/k-istorii-russkoy-tserkvi-v-godyi-velikoy-otechestve nnoy-voynyi-kommentariy-v-tsifrah-i-faktah.html. 
Pospielovsky, Dimitry. Vol. 1 of The Russian Church under the Soviet Regime. Crestwood, NY:

St. Vladimir's Seminary Press, 1984.

Richters, Katja. The Post-Soviet Russian Orthodox Church: Politics, Culture and Greater Russia. New York: Routledge, 2013.

Roslof, Edward E. Red Priests: Renovationism, Russian Orthodoxy, and Revolution, 1905-1946. Bloomington, IN: Indiana University Press, 2002.

Rousselet, Kathy. "The Russian Orthodox Church and Reconciliation with the Soviet Past." In History, Memory and Politics in Central and Eastern Europe: Memory Games, edited by Georges Mink and Laure Neumayer, 39-53. New York: Palgrave Macmillan, 2013.

Ryzhova, Svetlana. "Tolerance and Extremism: Russian Ethnicity in the Orthodox Discourse of the 1990s," in Religion and Identity in Russia, 65-90.

Stepaniants, Marietta. "Ethno-Religious Identity in Modern Russia: Orthodoxy and Islam Compared." In Religion and Identity in Russia: The Revival of Orthodoxy and Islam, edited by Juliet Johnson, Marietta Stepaniants, and Benjamin Forest, 26-38. Burlington: Ashgate Publishing Company, 2005.

Strickland, John. The Making of Holy Russia: The Orthodox Church and Russian Nationalism before the Revolution. Jordanville, NY: Holy Trinity Publications, 2013.

"Svyatei Patriarch Moskovskiy i vsyeya Rysi Kihrill vstrtilsya s veteranami Velikoi Otechestvennoi voiniy.” Moskovskaya Eparkhiya. Translated by Christian Basar. August 20, 2013. http://www.moseparh.ru/news/text/15431.html. 